Faculdade

de Ciências Econômicas UFRGS
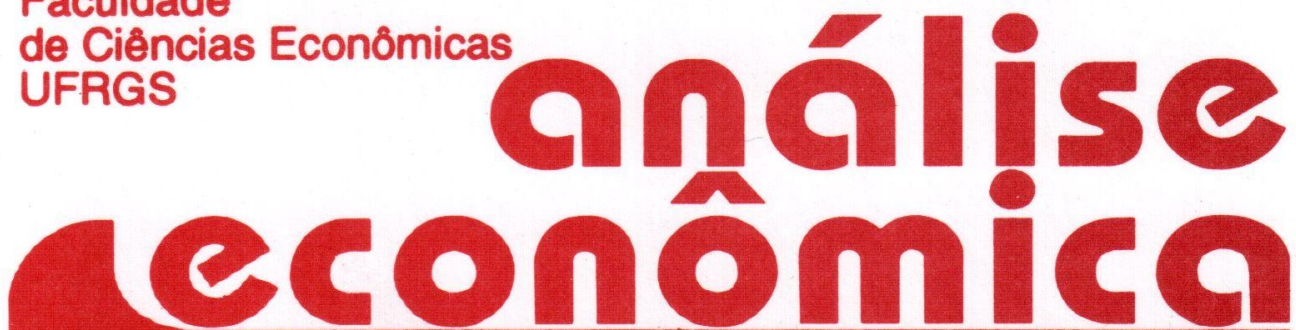

- SIDERURGIA E O PARADIGMA TECNOLÓGICO

Angela Maria Morandi

- ESTIMATING PRIVATE DEMANDS FOR PUBLIC GOODS

Eduardo Pontual Ribeiro

- KEYNES E A ATUALIDADE DA TEORIA KEYNESIANA

Fernando Ferrari Filho

- IMPRODUTIVIDADE DE UM CONCEITO DE PRODUÇÃO Raul Cristóvão dos Santos

- A NEGAÇÃo dA INEFICÁCIA DA POLÍTICA MONETÁRIA João Sicsú

- DESREgulamentAÇÃo, globa LIZAÇÃo E A CADEIA DO TRIGO Lena Lavinas

Manoel Magina

- ALUGUÉIS RESIDENCIAIS EM PORTO ALEGRE

Marco Aurélio Stumpf González

- POLICY INTERVENTION AND THE TRADE-OFF BETWEEN GROWTH AND DISTRIBUTION OF INCOME Joanílio Rodolpho Teixeira Jorge Thompson Araujo

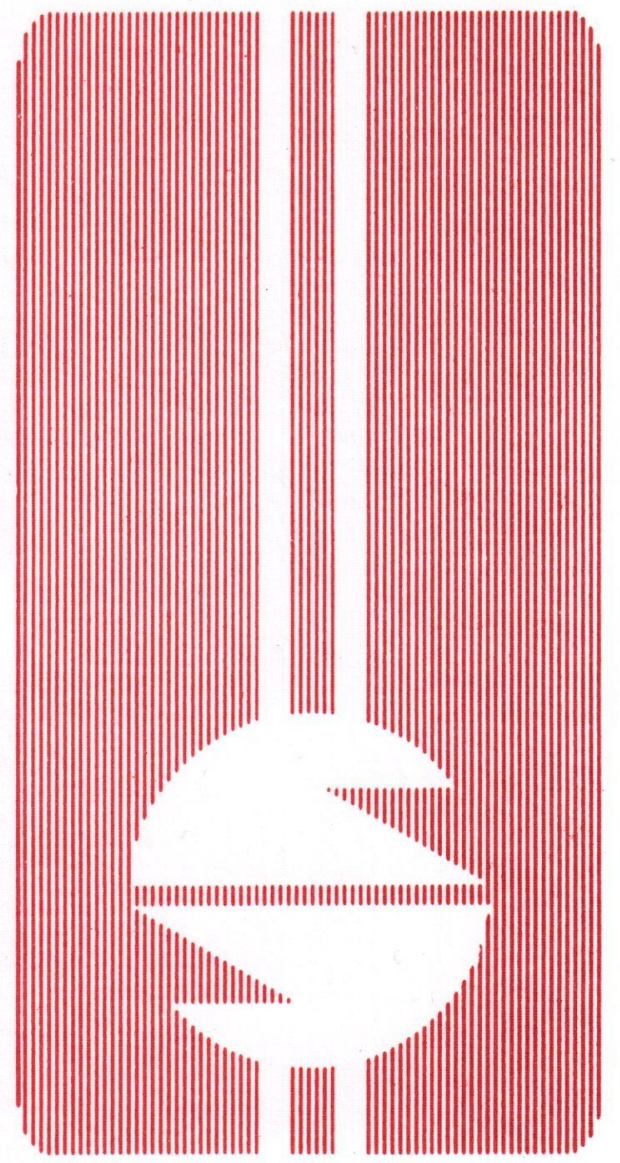


UNIVERSIDADE FEDERAL DO RIO GRANDE DO SUL

Reitora: Prof ${ }^{a}$. Wrana Maria Panizzi

FACULDADE DE CIENNCIAS ECONÓMICAS

Diretora: Prof ${ }^{\mathrm{a}}$. Otilia Beatriz Kroeff Carrion

CENTRO DE ESTUDOS E PEQUISAS ECONÔMICAS

Diretor. Prof. Fernando Ferrari Filho

DEPARTAMENTO DE CIÊNCIAS ECONÓMICAS

Chefe: Prof. Gentil Corazza

CURSO DE PÓS-GRADUAÇÃO EM ECONOMIA

Coordenador. Prof. Marcelo Savino Portugal

CURSO DE PÓS-GRADUAÇÃO EM ECONOMIA RURAL

Coordenador: Prof. Carlos Guilherme A. Mielitz Netto

CONSELHO EDITORIAL: Achyles B. Costa, Aray M. Feldens, Carlos A. Crusius, Carlos G. A. Mielitz Netto, Eduardo A. Maldonado Filho, Eduardo P. Ribeiro, Eugênio Lagemann, Fernando Ferrari Filho, Gentil Corazza, Marcelo S. Portugal, Nali J. Souza, Otília B. K. Carrion, Paulo A. Spohr, Paulo D. Waquil, Pedro C. D. Fonseca, Roberto C. Moraes, Ronald Otto Hillbrecht, Stefano Florissi, Eleutério F. S. Prado (USP), Fernando H. Barbosa (FGV/RJ), Gustavo Franco (PUC/RJ), João R. Sanson (UFSC), Joaquim P. Andrade (UnB), Juan H. Moldau (USP), Paul Davidson (Univ. of Tennessee), Werner Baer (Univ. of Illinois).

COMISSÃO EDITORIAL: Eduardo Augusto Maldonado Filho, Fernando Ferrari Filho, Gentil Corazza, Paulo Dabdab Waquil, Marcelo Savino Portugal, Roberto Camps Moraes.

EDITOR: Nali de Jesus de Souza

SECRETARIA: Cláudia Porto Silveira, Sandra Mascarello e Fábio Régis Sparremberger. Revisão de textos: Vanete Ricacheski.

FUNDADOR: Prof. Antônio Carlos Santos Rosa

Os materiais publicados na revista Análise Económica são da exclusiva responsabilidade dos autores. É permitida a reprodução total ou parcial dos trabalhos, desde que seja citada a fonte. Aceita-se permuta com revistas congêneres. Aceitam-se, também, livros para divulgação, elaboração de resenhas e recensões. Toda correspondência, material para publicação (vide normas na terceira capa), assinaturas e permutas devem ser dirigidos ao seguinte destinatário:

PROF. NALI DE JESUS DE SOUZA

Revista Análise Econômica - Av. João Pessoa, 52

CEP 90040-000 PORTO ALEGRE - RS, BRASIL

Telefones: (051) 316-3348 e 316-3440 - Fax: (051) 316-3990

nali@vortex.ufrgs.br 


\title{
A NEGAÇÃO DA INEFICÁCIA DA POLÍTICA MONETÁRIA: A ALTERNATIVA DE KEYNES E DOS PÓS-KEYNESIANOS*
}

\author{
João Sicsún \\ SINOPSE
}

Critica-se a principal base da macroeconomia novo-clássica, isto é, a taxa natural de desemprego. Em seguida, apresenta-se o conceito de economia monetária da produçåo, que constitui a base da macroeconomia keynesiana. A partir dessa idéia, argumenta-se que a política monetária pode ser um mecanismo eficiente para reduzir a taxa corrente de desemprego.

Cód. AEA: 331

Palavras-Chave: Taxa natural de desemprego, politica monetária, Keynes e os pós-keynesianos.

\begin{abstract}
The article criticizes the main hypothesis of the new classical macroeconomics, that is to say, the natural rate of unemployment. On the other hand, it shows that concept of monetary economy of production is the principal proposition of Keynesian macroeconomics. Finally, after confronting these ideas, the article argues that monetary policy can be vied to "solve" the unemployment problem.
\end{abstract}

Cód. AEA: 331

Key words: Natural rate of unemployment, monetary policy, Keynes and the post-keynesians

\section{INTRODUÇÃO}

A taxa natural de desemprego concebida por Milton Friedman é a hipótese básica assumida pelo monetarismo novo-clássico, a principal vertente do mainstream, que faz com que essa corrente descarte a

* Esse artigo está baseado no capítulo | da tese de doutorado do autor intitulada "Eficácia e Credibilidade da Política Monetária Discricionária: uma abordagem keynesiana", ver Sicsú(1997a).

*** Professor do Instituto de Economia da UFRJ, e-mail sicsu@ie.ufrj.br.

\begin{tabular}{|l|l|l|l|l|}
\hline ANÁLISE ECONÔMICA & ANO 15 & N. 28 & Setembro/97 & p. 80 - 107 \\
\hline
\end{tabular}


utilização de políticas monetárias discricionárias. Sem qualquer questionamento sobre o realismo da hipótese ou sobre a sua lógica interna, a taxa natural de desemprego tem sido cegamente aceita pelo seu valor de face - sua força decorre simplesmente de sua aceitação generalizada. A despeito da existência desse amplo movimento de apoio à taxa natural de desemprego, alguns autores têm apresentado argumentos que fragilizam a hipótese básica da economia novo-clássica, lançam argumentos que, no mínimo, geram desconfiança em relação à taxa natural.

Argumenta-se basicamente que a noção de equilíbrio representada pela taxa natural possui propriedades que não são válidas: não há nem estabilidade nem unicidade do equilibrio. Pós-keynesianos, céticos com a taxa natural, assumem, alternativamente, o conceito que Keynes chamou de economia monetária. Essa construção teórica é radicalmente diferente do arcabouço que envolve a teoria da taxa natural de desemprego da economia novo-clássica. O conceito keynesiano de economia monetária nega o principio da ergodicidade, a neutralidade da moeda em qualquer situação, a formação de expectativas do tipo racionais e demonstra que a política monetária é capaz de alterar em definitivo variáveis reais da economia. Tal perspectiva teórica norteou a elaboração deste artigo.

O texto nega a ineficácia da política monetária que é o principal corolário da escola novo-clássica. Conclui-se que uma administração monetária ativa pode ser eficaz para reduzir a taxa corrente de desemprego de forma permanente. Além disso, definem-se critérios para a utilização eficiente da política monetária.

O artigo está dividido em mais seis seções. A seção 2 apresenta 0 modelo novo-clássico. Na seção seguinte, faz-se a crítica à hipótese da taxa natural de desemprego. A seção 4 descreve a hipótese keynesiana alternativa à taxa natural. $\mathrm{Na}$ seção 5 , são definidos critérios para a aplicação de uma política monetária eficiente. A seção 6 descreve, segundo a teoria de Keynes e dos pós-keynesianos, os instrumentos de administração monetária e suas formas de operação. $\mathrm{Na}$ seção 7 , apresenta-se um sumário das principais conclusões do texto.

A relevância do tema desenvolvido no artigo está no ataque às bases que sustentam o inativismo da política monetária tido como necessário, inclusive por alguns governos durante as décadas de 1980 e 1990 e na defesa de uma posição que incorretamente tem sido acusada de causar inflação e de ser inócua quando objetiva reduzir a taxa de desemprego. 


\section{O MODELO MONETARISTA NOVO-CLÁSSICO E A INEFICÁCIA DA POLITICA MONETÁRIA}

A hipótese da existência de uma taxa natural de desemprego é o ponto de partida para a construção do corolário novo-clássico da ineficácia da política monetária. Tal hipótese foi formulada por Friedman (1968) como sendo aquela taxa adequada ao sistema de equilíbrio geral walrasiano que incorporaria as características estruturais e institucionais do mercado de trabalho e do mercado de bens, tais como, imperfeições, variações sazonais na demanda e oferta, o custo e o tempo de coletar informaçóes sobre vagas disponíveis e o custo e o tempo de mobilidade de um emprego para outro - entre outras características. ${ }^{1}$ A taxa natural seria aquela taxa que engloba o desemprego friccional e o desemprego voluntário. ${ }^{2} \mathrm{De}$ acordo com o arcabouço teórico monetarista-walrasiano, a taxa corrente de desemprego corresponderia à taxa natural de desemprego quando o conjunto de trabalhadores (empregados ou não) estivessem obtendo satisfação plena e quando as firmas estivessem auferindo lucros potenciais máximos.

A hipótese da taxa natural pode ser resumida na noção de que existe um ponto de desemprego (friccional e voluntário) de equilibrio na economia que possui as propriedades da estabilidade e da unicidade. Outra hipótese garante a estabilidade: mercados se equilibram via preços e salários, isto é, demandas e ofertas se igualam via concorrência. Quando a taxa corrente de desemprego coincide com a taxa natural, a economia encontra-se em posição de equilíbrio. Contudo, para a economia monetarista novo-clássica, o contrário não é verdadeiro. Independentemente da posição da taxa corrente de desemprego em relação à taxa natural, a economia estaria sempre em equilibrio desde que os agentes estivessem agindo

\footnotetext{
1 O termo natural foi usado, por Friedman, no sentido wickselliano separar as causas de natureza estrutural $e$ institucional das causas intervencionistas-monetárias. Nas palavras de Kregel, "como a taxa de juros natural de Wicksell era determinada por fatores reais fora da influência da política monetária, Friedman considera a sua taxa natural de desemprego única e fora do escopo da política monetária ela pode unicamente ser afetada por fatores reais, tais como, tecnologia, população, poupança e fricções ou regulações governamentais que impedem a operação do mercado" (1984-5, p. 144).

2 Tanto Friedman quanto os novos-clássicos enfatizam que a taxa natural não é imutável, nem inalterável. Muitas das características estruturais ou institucionais de uma economia, incluindo as preferências dos agentes, podem mudar com 0 passar do tempo, assim, mudando a taxa natural de desemprego. $E$, muitas das características institucionais podem ser alteradas por políticas, por exemplo, podem ser melhorados os processos de informação sobre a oferta de vagas disponiveis, dessa forma alterando a taxa natural de desemprego.
} 
racionalmente buscando maximizar suas preferências e tomando decisões coerentes com as suas funções-objetivo.

A chamada função oferta de Lucas, apresentada a seguir, mostra porque a política monetária é ineficaz quando o objetivo é reduzir a taxa corrente de desemprego $\left(U_{t}\right)$ em relação à taxa natural $\left(U_{n}\right)$.

$\mathrm{U}_{\mathrm{t}}=\mathrm{U}_{\mathrm{n}}-\mathrm{k}\left(\Delta \mathrm{P}_{\mathrm{t}}-\Delta \mathrm{P}^{\mathrm{Q}}\right)$

$\left(\Delta P_{t}\right.$ é a variação do nivel geral de preços do período $t, \Delta P^{e}$ é a variação do nivel de preços esperados para esse mesmo período e $\mathrm{k}$ é um parâmetro positivo). Pela equação 1, a taxa corrente de desemprego é igual a taxa natural quando a realidade confirma as expectativas de inflação. ${ }^{3}$ No modelo novo-clássico, as esperanças sobre variações do nível de preços são construidas de acordo com a teoria das expectativas racionais de Muth (1961), tal como mostra a equação 2:

$\Delta P^{e}=E\left(\Delta P_{t} / I_{t-1}\right)$

(que deve ser lida: a esperança de variação dos preços para o periodo $\mathrm{t}$ leva em consideração todas as informações, I, obtidas até o período imediatamente anterior, $t-1)$. As informações são processadas pelos agentes tendo como base o verdadeiro modelo que afeta os preços em uma economia que, segundo o monetarismo novo-clássico, é:

$\Delta P_{\mathrm{t}}=\Delta \mathrm{M}_{\mathrm{t}}$

$\left(\Delta \mathbf{M}_{t}\right.$ é a variação do estoque de moeda no periodo $\left.t\right)$. Então, as expectativas de variação do nivel de preços estão diretamente relacionadas com as expectativas de variação do estoque monetário, como mostra a equação 4:

$\Delta \mathrm{P}^{\mathrm{e}}=\Delta \mathrm{M}^{\mathrm{e}}$

$\left(\Delta M^{e}\right.$ é a variação esperada do estoque monetário para o periodo t). Das equações 2, 3 e 4 têm-se que se os agentes conhecem a regra de variação do estoque monetário $\left(\Delta M^{e}=\Delta M_{t}\right)$, então, jamais haveria decepção de expectativas de preços. E substituindo as equações 3 e 4 na função 1 , obtém-se:

\footnotetext{
${ }^{3}$ A função oferta de Lucas poderia ser representada por uma fórmula mais ampla que a equação 1, a saber: $U_{t}=U_{n}-k\left(\Delta P_{t}-\Delta P^{e}\right)+\beta$, em que o termo $\beta$ representa todos os outros fatores nåo-monetários capazes de afastar a taxa de desemprego corrente da taxa natural, tais como, choques tecnológicos. Optou-se por utilizar uma forma mais restrita dado o escopo do tema em discussão que refere-se exclusivamente às variáveis preço, moeda e expectativas
} 
que indica que a taxa corrente de desemprego seria sempre igual a taxa natural se os agentes conhecessem a regra de variação do estoque monetário. Portanto, pode-se concluir que, segundo a teoria da política monetária novo-clássica, partindo-se de uma situação em que $U_{t}=U_{n}$ e 0 governo anuncia um aumento da oferta de moeda, os agentes reagiriam à decisão dos policymakers exclusivamente aumentando os seus preços, sem contratar qualquer trabalhador adicional. Assim, a taxa corrente de desemprego permaneceria repousada sobre a taxa natural. Em outras palavras, as decisões de políticas monetárias expansionistas conhecidas pelos agentes não provocariam qualquer aumento no nível de emprego e do produto real - causariam simplesmente aumento do nivel geral de preços equivalente ao aumento do estoque de moeda.

Esse simples modelo de ineficácia da política monetária foi apresentado por Sargent \& Wallace (1981), em artigo publicado originalmente em 1975. Contudo, mostraram ainda que unicamente políticas monetárias que causam surpresa poderiam provocar efeitos reais (ainda que passageiros) na economia. Para tanto, bastaria que o governo adotasse uma regra de expansão monetária, por exemplo,

$\Delta \mathrm{M}^{\mathrm{t}}=\delta\left(\mathrm{U}_{\mathrm{t}-1}-\mathrm{U}_{\mathrm{n}}\right)+\phi$

( $\delta$ é um parâmetro positivo e $\phi$ um elemento de política monetária somente conhecido pelos policymakers e eventualmente utilizado). Logo, agentes racionais formariam suas expectativas de variação do estoque monetário com base na regra explícita,

$\Delta M^{e}=\delta\left(U_{t-1}-U_{n}\right)$.

Substituindo-se as equações 6 e 7 em 5 tem-se,

$\mathrm{U}_{\mathrm{n}}-\mathrm{U}_{\mathrm{t}}=\mathrm{k} \phi$.

A equação 8 mostra que a taxa corrente de desemprego somente não coincide com a taxa natural quando o elemento $\phi$ é acionado pelos policymakers causando surpresa aos agentes porque, dessa forma, $\Delta \mathrm{M}_{\mathrm{t}} \neq$ $\Delta \mathrm{M}^{\mathrm{e}} \Rightarrow \Delta \mathrm{P}_{\mathrm{t}} \neq \Delta \mathrm{P}^{\mathrm{e}}$. Qualquer conjunto de decisões individuais que possa afastar a economia da taxa natural é necessariamente fruto de erros expectacionais. No modelo novo-clássico, agentes privados erram porque são surpreendidos. A surpresa é sempre fruto da introdução de novas variáveis no mundo real ou da alteração inesperada da magnitude de variáveis já existentes e, portanto, integrantes do modelo subjetivo que processa as expectativas racionais dos agentes econômicos. No caso de intervenções monetárias discricionárias, a surpresa ocorre em função de 
alterações não-antecipadas do estoque de moeda, que resultam em erros expectacionais e, conseqüentemente, em alguma discrepância entre a taxa de desemprego corrente e a taxa natural.

Empresários, com restrição informacional devido à utilização do elemento $\phi$, ainda que formando expectativas racionais, entenderiam incorretamente o movimento de preços decorrente da variação do estoque monetário e expandiriam a sua produção contratando mais trabalhadores: entenderiam que 0 aumento de preços não estaria sendo provocado por um aumento de oferta monetária, mas sim, por um real aumento de demanda por seus produtos. Assim, estariam estimulados a contratar mais trabalhadores já que a regra de maximização de lucros praticada é receita marginal igual ao custo marginal. Dessa forma, empresários poderiam oferecer aos trabalhadores voluntariamente desempregados um salário real esperado maior do aquele que rejeitam dada a satisfação propiciada pelo lazer. Com todas as firmas contratando trabalhadores acima do seu potencial, a taxa corrente de desemprego seria menor do que a taxa natural.

Transcorrido o tempo necessário ao entendimento do verdadeiro movimento das variáveis estoque de moeda e preços por parte do conjunto de agentes da economia, parte dos trabalhadores retornaria à condição de desempregados voluntariamente e a produção se reduziria para o patamar original correspondente à taxa natural de desemprego. Trabalhadores perceberiam que o salário nominal maior não significou um aumento real de salários e empresários perceberiam que o aumento de preços não era relativo a seu favor, mas sim, que era um aumento absoluto e neutro. Conseqüentemente, a taxa corrente de desemprego retornaria ao seu nivel considerado natural.

Em uma das suas críticas à dinâmica macromonetária descrita pelos novos-clássicos, Tobin (1996, p.412) afirmou que, se os pressupostos do monetarismo de Sargent \& Wallace (1981) fossem válidos, a política monetária tornar-se-ia totalmente impotente com o passar do tempo em razão que a estratégia da surpresa não poderia funcionar continuamente porque os agentes aprenderiam, inclusive, o modelo decisório dos policymakers. Ademais, não faz sentido para Tobin um modelo que descreve um mundo em que a eficácia da política monetária dependeria do desapontamento dos agentes e, posteriormente (após o período de aprendizado), a política monetária se tornaria (para sempre) ineficaz. Assim, Tobin indagou: "isso faz sentido?" (idem). Embora não tenham respondido diretamente a Tobin, Kydland \& Prescott (1994) tentaram mostrar que, de fato, a surpresa propiciada pelo elemento $\phi$ pode desaparecer da economia novo-clássica e com ela a possibilidade de implementação de políticas monetárias de redução (ainda que passageira) 
do desemprego. A próxima subseção faz uma crítica às conclusões de Kydland \& Prescott (1994).

\subsection{Inconsistência nos desenvolvimentos do corolário novo-clássico}

Segundo Kydland \& Prescott (1994), em artigo publicado originalmente em 1977, sempre existirão incentivos à utilização do elemento $\phi$ porque policymakers por hipótese possuem uma propensão a gerar inflação (inflationary bias) com o objetivo de reduzir o desemprego corrente em relação ao seu ponto de equilíbrio representado pela taxa natural. $O$ viés inflacionário se expressaria através da implementação de políticas monetárias que são ditas dinamicamente inconsistentes. Tornar-se-ia, entretanto, impossivel aos policymakers obter qualquer redução do nível de desemprego porque os agentes econômicos possuiriam um modelo subjetivo para a tomada de decisão que consideraria, inclusive, o modelo decisório (verdadeiro) de política monetária das autoridades. Nas palavras de Kydland \& Prescott (1994, p. 35-6), "tudo que é necessário para o nosso argumento é que agentes tenham algum conhecimento de como decisões dos policymakers mudarão como resultado de mudanças nas condições econômicas" (o primeiro termo da frase foi grifado pelos autores). Assim, qualquer política monetária expansionista discricionária seria antecipada e anulada em termos reais, seus efeitos seriam somente sobre o nivel de preços. Para Kydland \& Prescott, as expectativas quanto à variação do estoque monetário deveriam ser expressas pela equação:

$\Delta \mathrm{M}^{\mathrm{e}}=\delta\left(\mathrm{U}_{\mathrm{t}-1}-\mathrm{U}_{\mathrm{n}}\right)+\phi$.

Assim, haveria sempre as igualdades:

$$
\begin{aligned}
& \Delta M^{e}=\Delta M_{t} \Rightarrow \Delta P^{e}=\Delta P_{t} \quad e \\
& U_{t}=U_{n} .
\end{aligned}
$$

O argumento de Kydland \& Prescott (1994) é um avanço na estrada do mainstream para mostrar que políticas monetárias discricionárias são ineficazes e seu uso por parte de policymakers deve, portanto, ser desaconselhado. Enquanto, Sargent \& Wallace (1981) mostraram que somente políticas monetárias que causam surpresa poderiam provocar efeitos reais (ainda que passageiros), Kydland \& Prescott mostraram que seria impossivel haver surpresa porque 0 modelo que processa as expectativas racionais dos agentes levaria em consideração, também, o modelo decisório (objetivo) dos policymakers. Para Kydland \& Prescott (1994), tanto o elemento $\phi$ quanto os critérios de sua utilização são conhecidos por todos os agentes, isto é, policymakers e público. 
que cabe ser perguntado à Kydland \& Prescott (1994) é: somente policymakers desconhecem que não são capazes de surpreender os agentes e continuam inflacionando as economias sem saber que não conseguirão impactar variáveis reais? Policymakers sabem que o público conhece o seu modelo de tomada de decisão? Se a resposta a essa ultima pergunta for negativa, o modelo de Kydland \& Prescott estaria assumindo que todos os agentes formam expectativas racionais, menos os policymakers! Se a resposta for positiva, o modelo careceria de lógica interna porque os policymakers estariam dispostos a realizar algo que saberiam ser impossivel.

\section{CRITICAS À TAXA NATURAL DE DESEMPREGO}

Um dos teóricos mais reconhecidos por seus trabalhos sobre o tema equilibrio geral walrasiano, Frank Hahn, é mais cauteloso e, talvez, cético em relação à hipótese da $U_{n} \mathrm{e}$, conseqüentemente, ao monetarismo. Interpreta essa corrente como sendo a doutrina que descreve o mundo real como uma economia perfeitamente competitiva em equilíbrio walrasiano. (Hahn, 1984, p.307) Entretanto, considera que o modelo Arrow-Debreu (o sucessor moderno do sistema de equações de Walras) não é interpretativo da economia real, assim, aduziu: "tendo gasto a maior parte da minha vida como um economista dessa teoria [o modelo Arrow-Debreu], confesso que tal interpretação nunca me ocorreu" (Hahn, 1984, p.308).

Nas duas próximas subseções são apresentadas, de forma sintética, as críticas de Hahn e de outros autores às propriedades da estabilidade e da unicidade do equilíbrio descrito pela taxa natural de desemprego.

\subsection{A estabilidade do equilibrio}

O modelo Arrow-Debreu, segundo Hahn (1984, p.308), "não descreve a mão invisivel em movimento, mas apenas mostra sua tarefa realizada". Hahn $(1984$, p.47) afirmou ainda que a construção do equilíbrio geral "... não faz nenhuma colocação formal ou explicitamente causal: por exemplo, não contém nenhuma presunção de que uma seqüência de estados econômicos reais terminará em um estado de equilíbrio". Hahn questionou a validade da propriedade da estabilidade. Contrariamente, novos-clássicos aceitam com tranqüilidade a descrição teórica e empírica da propriedade da estabilidade: a taxa corrente de desemprego move-se sempre rumo à $U_{n}$. Contudo, o teórico do modelo Arrow-Debreu afirmou, "... ninguém mostrou que, de fato, uma economia sempre busca aquele equilíbrio. Eu não quero dizer que 
ninguém mostrou 'empiricamente'. Quero dizer que ninguém mostrou isso teoricamente ..." (Hahn, 1984, p.315). ${ }^{4}$

Para os novos-clássicos, a propriedade da estabilidade é crucial. Sem essa propriedade a definição de uma posição de equilíbrio $\left(U_{n}=U_{t}\right)$ perderia qualquer validade nos modelos de Friedman ou Lucas. A $U_{n}$ deve ser interpretada segundo sua origem e evolução dentro do caminho de desenvolvimento do pensamento econômico (Shulman, 1989, p.509): a taxa natural de desemprego é a equivalente moderna da taxa de pleno emprego da economia pré-keynesina - a economia do laissez-faire. Nesse sentido, a $U_{n}$ não pode ser reinterpretada como a taxa de pleno-empregocom-desemprego elaborada pelo velho-keynesiano Arthur Okun. A taxa elaborada por Friedman é uma construção teórica que vai muito além de uma simples descrição de uma posição de equilíbrio da economia. Se a $U_{n}$ é utilizada como referência teórica, a análise deve necessariamente aceitar a existência de forças endógenas que automaticamente equilibram mercados, então, conseqüentemente, a taxa corrente de desemprego flutuaria em torno e em direção à $U_{n}$. Portanto, "a taxa natural de desemprego é uma conclusão analítica sobre o comportamento do mercado mais do que um puro e simples objetivo de politica [macroeconômica]" (Shulman, 1989, p.510).

Hahn considera que a estabilidade é uma propriedade forjada pelos monetaristas com o intuito de justificar o resultado que pretendem a priori encontrar. Assim, disse: "... [eles] têm um pé nas águas tranqüilas do modelo Arrow-Debreu e outro em aparentemente plausíveis modelos ad hoc [e é isso] que faz o trabalho desses economistas tão insatisfatório" (1984, p.309). Mas porque a propriedade da estabilidade seria um argumento ad hoc? Segundo Hahn (1984, p.315), Lucas reconhece que erros racionalmente cometidos não são descartados do modelo subjetivo que processa as expectativas racionais de um individuo ou de um grupo. Entretanto, para o estudioso do modelo Arrow-Debreu, Lucas não tem considerado o que tal possibilidade provocaria na sua teoria. Se modelos subjetivos podem diferir do modelo real em função da manutenção de erros racionalmente cometidos, o conjunto de expectativas dos agentes poderia

\footnotetext{
${ }^{4}$ Críticas à $U_{n}$ em aspectos empíricos-operacionais sáo feitas, inclusive, por importantes economistas ortodoxos. William Fellner, por exemplo, disse que "a hipótese da taxa natural de desemprego nảo pode ser levada além da teoria da perfeita competiçăo para as dadas imperfeições dos mercados reais...". Edmond Malinvaud comentou que Friedman não fez "nenhuma tentativa ... para aplicar diretamente ... [sua] definição para a economia $\theta$, de fato, o sistema Walrasiano suposto seria ainda obscuro" e Robert Solow "duvida que muitos que usam o conceito aceitariam a definição de Friedman, ou imaginariam estimativas econométricas da taxa natural para servirem de estimativas de um componente do equilibrio Walrasiano ..". Essas criticas foram citadas por Shulman $(1989$, p.512).
} 
não ser homogêneo ${ }^{5}$ Conseqüentemente, decisões de retorno a posições originais de maximização poderiam não ocorrer para todas as unidades de decisão econômica porque nem todas ao confrontar a realidade com suas expectativas concluiriam que a melhor decisão seria a negação integral da decisão que reduziu seu nivel de satisfação. Assim, a taxa corrente de desemprego não se igualaria a $U_{n}$. Em conseqüência, Hahn (1984, p.316) argumentou ainda que "... agentes podem saber um modelo da economia, mas não existe o modelo da economia, já que não existe forma pela qual eles possam modelar cada erro dos outros".

\subsection{A unicidade do equilibrio}

Os descontentamentos de Hahn com a hipótese da $U_{n}$ ultrapassam as críticas à propriedade da estabilidade. Hahn $(1984$, p.321) afirmou que: "... até que o estado de equilibrio seja alcançado existirão muitas diferentes evoluções do que tem sido tão tendenciosamente chamado de nível de desemprego natural...". As características do mercado de trabalho e de bens podem evoluir no periodo de tempo que ligaria expectativas à realidade. Portanto, a cada estado expectacional da economia poderiam ocorrer mudanças nos parâmetros que conformam a realidade econômica logo, a própria taxa natural de desemprego estaria sujeita a mudar de posição. Por conseguinte, a $U_{n}$ poderia não conter inclusive a propriedade da unicidade: a relação existente entre oferta e demanda por trabalho, embora fosse de equilíbrio à $U_{n}$, seria instável.

Davidson (1978, p.370) argumentou, ainda, que erros expectacionais, seja com expectativas adaptativas ou racionais, podem induzir os agentes a mudar alguns parâmetros que sustentam a $U_{n}$, dessa forma, mudando a taxa natural de desemprego de posição. A visão de Davidson é mais cética do que a de Hahn, para ele a $U_{n}$ pode mudar de posição não por evolução, mas por indução. Heterogeneidade de expectativas resulta necessariamente em erros: esses, por sua vez, podem induzir a mudanças de parâmetros, tais como gostos e preferências (Davidson, 1982, p.13).

\footnotetext{
${ }^{5}$ Segundo Simonsen (1986, p 251-2), novos-clássicos recorrem as seguintes hipóteses para explicar a tomada de decisões a partir da formação de expectativas racionais: (i) os agentes econômicos conhecem um modelo quantitativo que, salvo a ocorrência de perturbações estocásticas, determina o comportamento das variáveis endógenas em função das exógenas, (ii) todos os agentes econômicos dispõem do mesmo conjunto de informações e tais informações são interpretadas da mesma maneira e (iii) os agentes econômicos chegam as mesmas previsóes das variáveis endógenas, isto é, as expectativas são homogêneas. Entretanto, D. Laidler, um monetarista, afirmou: "...nós devemos enfrentar a implicação que a heterogeneidade das expectativas em qualquer momento é mais provável ser a regra que a homogeneidade" (citado em Davidson, 1982, p.13)
} 
Kregel (1984-5, p.143-4) argumentou que seria um erro admitir que existe a taxa natural de desemprego. Friedman (1968) afirmou que sua $U_{n}$ foi construída com base na taxa natural de juros de Wicksell. Essa taxa é aquela que iguala a poupança ao investimento e que mantém inalterado um nivel qualquer de preços para um dado nível de emprego (ver Wicksell, 1986, p. 275) A taxa de juros natural pode estar situada em um patamar cuja elasticidade do produto e do emprego seja zero, mas essa seria apenas uma situação particular (uma das possibilidades existentes) - essa taxa foi chamada por Keynes de taxa de juros neutra (CW, v.7, p.243). A teoria prékeynesiana assumiu a hipótese que a taxa de juros de mercado seria sempre igual a taxa de juros neutra, portanto, a economia clássica é a economia da elasticidade zero do produto e do emprego. Contudo, Kregel afirmou que igualdade entre poupança e investimento ex-post com preços inalterados é possivel para uma variedade infinita de niveis de desemprego. Conseqüentemente, cada nível de desemprego que possuísse uma taxa natural de juros poderia ser considerado, também, natural. Logo, assim como a taxa de juros natural prescinde do pleno emprego da economia clássica, a $U_{n}$ de Friedman prescindiria da necessidade de ser única. Ademais, mudanças freqüentes e intensas na taxa natural de juros eram aceitas por Wicksell, ${ }^{6}$ logo, tais mudanças deveriam ser aceitas por Friedman em relação a sua $U_{n}$. Em suma, Kregel mostrou que a base teórica que deu origem e sustenta a $U_{n}$ nega a necessidade da propriedade da unicidade.

\section{A ALTERNATIVA DE KEYNES E DOS KEYNESIANOS À TAXA NATURAL. DE DESEMPREGO}

Assim como Keynes não aceitou as bases clássicas que resultavam no pleno emprego, os keynesianos não assumem a hipótese da $U_{n}$. Keynes estabeleceu as linhas gerais do conceito chamado economia monetária que foi amplamente desenvolvido, especialmente, pelos pos-keynesianos. ${ }^{7} \mathrm{Na}$ sua visão, a moeda joga um papel fundamental, afeta motivações e decisões sobre preços, produção e investimento. Logo, a política monetária é considerada potente para alterar estados reais da economia. No modelo

\footnotetext{
${ }^{6}$ Segundo Wicksell (1986, p. 283) " a diferença entre as taxas efetivas dos empréstimos e a taxa natural ( ) não surge menos frequentemente porque as taxas dos empréstimos mudam espontaneamente, enquanto a taxa de juros real ou natural permanece invariável, e sim porque a taxa natural sobe ou baixa enquanto a taxa dos empréstimos permanece invariável ou se altera muito lentamente (..) A taxa de juros natural (...) está, como qualquer outra coisa, sujeita a mudanças às vezes muito intensas".

7 Descrições sistematizadas do conceito lançado por Keynes podem ser encontradas, por exemplo, em Davidson (1984) e Kregel (1980).
} 
de Keynes, portanto, a moeda não é prescindível, tal como é para o esquema de equilibrio Arrow-Debreu. Tal conclusão aparece na primeira frase do primeiro capitulo do livro Money and Inflation de Hahn. Ele afirmou que, "o mais sério desafio que a existência da moeda apresenta aos teóricos é que: o mais desenvolvido modelo de economia não pode encontrar lugar para ela. O mais desenvolvido modelo é, com certeza, a versão Arrow-Debreu de um equilíbrio geral walrasiano" (Hahn, 1983, p.1).

A economia monetária de Keynes descreve um mundo capitalista de livre mercado em que firmas, por um lado, e trabalhadores, por outro, objetivam obter e acumular o máximo de rendimentos e riquezas monetárias. A preferência por liquidez presente nesse modelo baseia-se no fato de que a moeda, mais do que qualquer outro ativo, é capaz de deixar o agente numa posição mais fluida, isto é, livre para adotar novas estratégias em um mundo incerto. A incerteza assumida por Keynes e keynesianos é definida como um conjunto de conjecturas sobre um contexto futuro que não está sujeito ao cálculo probabilístico de resultados possiveis. Diferentemente, o resultado futuro de um jogo de roleta, a expectativa de vida de uma população ou o índice pluviométrico futuro de um país são exemplos de situaçốes que estão sujeitos a incertezas estatisticamente previsiveis. Para keynesianos, a incerteza presente na economia é do tipo knightiana em oposição à incerteza presente em contextos ergódicos sugerida por John Muth e assumida pela teoria novo-clássica. No modelo de Keynes, cada agente busca uma série de normas para agir e se defender contra o futuro totalmente inesperado: a retenção de liquidez na forma monetária é a mais comum dessas regras práticas.

A característica principal do conceito de economia monetária que o diferencia da hipótese da taxa natural de desemprego é a não neutralidade da moeda em quaisquer circunstâncias. Para uma dada quantidade de bens de investimento, o nível de emprego/produção pode sofrer variações devido a uma redução (ou aumento) da demanda por bens proveniente de decisões de aumentar (ou reduzir) a retenção de moeda. Relaxando-se a restrição de dado o estoque capital, uma economia também pode ser afetada pelas decisões individuais referentes à moeda. A acumulação de riqueza monetária definirá o padrão de acumulação real de uma economia porque decisões de investir ou de reter riqueza monetária são mutuamente exclusivas. A propriedade crucial da moeda é ser reserva de valor, assim, é uma alternativa à aquisição de ativos de capital porque satisfaz os desejos da comunidade de acumular riqueza. (Tobin, 1972, p.146-7) Se, por um lado, a moeda é capaz de acalmar a inquietude dos possuidores de riqueza frente ao futuro incerto (CW, v.14, p.116), por outro, bens de capital, para serem preferidos, devem oferecer ao investidor potencial uma compensação a fim de estimulá-lo a trocar a sua riqueza liquida por uma 
riqueza ilíquida. Quando essa compensação não é suficiente para estimular decisões de investimento, a preferência pela liquidez predomina, então, as variações positivas da renda e do nivel de emprego tendem a se reduzir.

Teóricos adeptos da $U_{n}$ admitem que alterações do nivel de emprego somente ocorrem quando existem mudanças das preferências sociais entre trabalho e lazer, variações do estado das artes que alteram a produtividade e choques exógenos causados pelas autoridades monetárias. Diferentemente, pós-keynesianos percebem que o nivel de emprego pode flutuar devido a mudanças de avaliações subjetivas à respeito do futuro incerto que provocam decisões de portfólio a favor de ativos mais líquidos, em especial, a retenção de moeda. Portanto, é o papel desempenhado pela moeda que fundamenta as conclusões de Keynes a respeito da dinâmica capitalista. Assim, afirmou: "a idéia que é comparativamente fácil adaptar as conclusões hipotéticas de uma economia de salário real para o mundo real da economia monetária é um erro..." (CW, v.13, p.410).

$\mathrm{Na}$ visão de Keynes e dos pós-keynesianos, é a presença da moeda desempenhando o papel do ativo mais seguro em uma economia com incerteza knightiana que pode explicar a possibilidade de existência de diversos níveis de desemprego, cada um desses niveis sendo capaz de persistir por longos períodos, até que haja uma modificação no estado expectacional da economia e/ou uma intervenção governamental. Diferentemente da economia novo-clássica, para Keynes e os póskeynesianos não existe uma taxa única de desemprego capaz de vigorar na ausência de erros expectacionais. A economia pode alcançar infinitas posições de desemprego, cada uma correspondente a um estado expectacional que, por sua vez, está associado a um determinado estado de preferência pela liquidez. A política monetária anti-desemprego de inspiração keynesiana visa à alteração desses estados.

$\mathrm{Na}$ economia monetária de Keynes, as políticas de intervenção via banco central tentam induzir os agentes a tomar decisões consistentes com determinados objetivos relativos ao uso da liquidez disponivel. Uma política monetária que visa à redução do desemprego deve estimular os animal spirits da economia de tal forma que a incerteza futura tenha uma influência mais restrita sobre as decisões de investimento: busca-se aumentar o retorno total esperado relativo dos ativos de capital. Dessa forma, uma alteração de composição de portfólio do público a favor da aquisição de máquinas e realização de obras tornar-se-ia menos arriscada. A troca da liquidez da moeda com rendimento nulo pela iliquidez dos ativos de capital com retornos esperados positivos deve se transformar, pela ação da política monetária, na opção mais rentável e segura para os agentes, conseqüentemente, reduzindo o desemprego. Em suma, manipulações da política monetária devem tentar provocar mudanças de preços relativos de 
diversos ativos da economia, dos mais líquidos aos mais ilíquidos, induzindo decisões de portfólio que atingiriam as variáveis reais da economia.

$\mathrm{Na}$ concepção keynesiana assumida, portanto, o uso discricionário da política monetária não é considerado um erro teórico e/ou uma inocuidade tal com sugerem Friedman (1968), Sargent \& Wallace (1981) e Kydland \& Prescott (1994). Sendo assim, utilizar-se-á a seção seguinte para apresentar três critérios para a utilização eficiente dos instrumentos de política monetária.

\section{KEYNES E OS CRITÉRIOS DE EFICIÊNCIA DA POLÍTICA MONETÁRIA}

Segundo a teoria da política econômica de Tinbergen (1952), o número de objetivos almejados pelos policymakers deve ser inferior ao número de instrumentos que podem ser utilizados. Caso contrário, pelo menos um objetivo não seria alcançado se existir trade-off entre eles. Sendo assim, cada objetivo deve ter pelo menos um instrumento correspondente. Embora essa seja uma condição necessária não é suficiente para o sucesso de uma intervenção macroeconômica. A coordenação na utilização dos instrumentos torna-se fundamental quando um objetivo possui mais de um instrumento que pode ser acionado.

Para o receituário pós-keynesiano de política monetária, a coordenação da utilização de instrumentos de intervenção macroeconômica é fundamental. Quanto mais coordenados estiverem os instrumentos monetários entre si e esses, por sua vez, com os instrumentos fiscais, mais eficiente provavelmente será a política monetária. A coordenação é necessária porque, como afirmou Cairncross (1992, p.198), "todos os instrumentos de política econômica interagem. O que ocorre quando se utiliza qualquer instrumento depende do estado dos demais instrumentos de política e das condições que prevalecem naquele momento". Cada instrumento utiliza um canal de transmissão diferente agindo com timing e intensidades diversas, mas todos afetam uma única variável, a demanda. Logo, é imprescindivel a coordenação da utilização das várias ferramentas que agem sobre o mesmo objeto, a demanda. ${ }^{8}$

\footnotetext{
8 A atenção de Keynes dada à necessidade de coordenação dos instrumentos de política monetária entre si e, simultaneamente, com os instrumentos de política fiscal foi expressa, por exemplo, no seu plano de busca do pleno emprego para a Inglaterra no final dos anos 1930 - o período imediatamente anterior a Guerra Keynes sugeriu que: deveriam ser evitadas taxas de juros mais altas - a taxa de juros de longo termo não deveria exceder $2 \frac{1}{2}$ $\%$ a taxa de juros bancária deveria ser mantida em torno de $2 \%$ a a , uma política fiscal de taxação seria a base para a obtenção de recursos reais por parte do Governo visando à
} 
Embora a coordenação da utilização dos instrumentos de política macroeconômica seja imprescindível para a realização de uma política monetária bem sucedida, outros dois critérios devem ser observados para o julgamento sobre a eficiência de uma determinada ação monetária. Uma política monetária eficiente seria aquela que, além de criar o mínimo de utilização-contraditória entre seus instrumentos e os instrumentos de política fiscal, persegue um objetivo não-ambíguo e, também, emite o máximo de sinais aos agentes a fim de estimulá-los a agir no mesmo sentido da direção apontada/adotada pelas autoridades. Assim, uma política monetária keynesiana eficiente busca preparar um ambiente apropriado (tal como um jardineiro) para a tomada de decisões individuais favoráveis aos objetivos desejados - e não moldar resultados finais (como faz um artesão). ${ }^{9}$

\subsection{Coordenação versus subordinação}

O critério da coordenação da utilização de instrumentos não deve ser incorretamente entendido como subordinação da política monetária à fiscal. Chick verificou que, na Inglaterra por exemplo, a política monetária era subordinada à política fiscal. No início dos anos 1970, constatou que grande parte da política monetária dedicava-se simplesmente a assegurar que a política fiscal fosse financiada e levada adiante. Essa visão deixava a política fiscal numa posição de força e a política monetária numa posição subordinada (Chick, 1993, p.12). Chick reconheceu ainda que a inflação dos anos 1960 resultou desse tipo de atuação do Bank of England. No receituário keynesiano, regras de política econômica devem ser precisas para se evitar que as autoridades monetárias sejam obrigadas a acomodar decisões fiscais que sacrificam objetivos monetários. A preservação da ordem monetária e fiscal deve definir limites e restrições ao uso de instrumentos monetários. As palavras de Tobin referentes a esse ponto específico merecem destaque, ...tenho argumentado que as autoridades monetárias não deveriam, em verdade não podem, fugir da responsabilidade por resultados macroeconômicos reais. [Contudo], para

compra de armamentos; através da emissão de papéis com maturidades diferenciadas, o Governo deveria permitir aos agentes manter a estrutura de maturidade de dívida pública desejada, assim, preferências poderiam ser exercidas e se evitaria de se ter de oferecer taxas de juros mais elevadas para compensar uma liquidez menor de um ativo-papel; as autoridades deveriam estar atentas para absorver a poupança (via emissão de dívida) gerada por um gasto do Governo, assim, pressões seriam evitadas sobre o mercado de bens $\theta$ de ativos financeiros - logo, poderia ser preservada a estrutura de taxas de juros almejada Essas medidas foram descritas por Moggridge (1993, p. 129).

${ }^{9}$ As metáforas utilizadas são de Hayek (1985, p.69). 
evitar mal entendimento, afirmo com toda firmeza que não estou advogando que elas não se preocupem com resultados nominais, níveis de preço e taxas de inflação. Em alguma parte do arcabouço de metas e objetivos de política monetária devem existir âncoras nominais que previnam a acomodação ilimitada e dêem o devido peso aos custos e a insatisfação da sociedade com a inflação". (Tobin, 1996, p.478)

Quando os instrumentos de administração monetária estão subordinados a objetivos fiscais, a política monetária não é eficiente. A despeito do governo adotar um único objetivo prioritário, a relação simbiótica monetária-fiscal emite sinais que estimulam as expectativas inflacionarias dos agentes. Portanto, são sinais que fazem aumentar a incerteza em relação ao futuro e, portanto, tendem a inibir a ação dos agentes. Logo, diante do provável desestímulo privado, o governo deverá utilizar os instrumentos de política fiscal e monetária mais intensamente e por mais tempo. Nesse contexto, a política monetária não pode ser considerada eficiente simplesmente porque pode alcançar seu objetivo. A avaliação sobre a eficiência de uma política econômica deve levar em consideração, além dos critérios já mencionados, os efeitos colaterais gerados. $E$, nesse caso, ambas as políticas econômicas provavelmente provocariam inflação.

Policymakers e agentes privados interagem permanentemente com movimentos de ação-e-reação. No caso de estruturas de subordinação da política monetária à fiscal, as expectativas inflacionárias dos agentes se tornam mais nervosas em função do aprendizado de que políticas de expansão do produto são financiadas com a utilização de instrumentos que ameaçam à estabilidade de preços. Logo, ações governamentais que buscam a redução do desemprego poderiam ser acompanhadas por reações precificadoras e pela paralisação das atividades de investimento em função da incerteza gerada pelo cenário esperado de inflação futura. Conseqüentemente, tal política expansionista é ineficiente porque, primeiro, não emite sinais que estimulam (re)ações do público no mesmo sentido da política governamental, assim obrigando o uso intensivo e por um tempo mais longo dos instrumentos de política macroeconômica. E, segundo, causaria efeitos colaterais danosos à economia: a inflação e o engavetamento de projetos de investimento.

Segundo os princípios da escola novo-clássica, políticas de administração da demanda agregada não devem ser utilizadas para alterar a taxa corrente de desemprego - que na ausência de erros expectacionais está repousada sobre a taxa natural. Portanto, não há razão dentro da rationale ortodoxa, para se pensar no problema da coordenação de políticas econômicas que visam à redução do nivel de desemprego ou, equivalentemente, ao aumento do produto. Para a ortodoxia, a 
coordenação entre políticas ocorreria tão somente com a adoção de um orçamento equilibrado e de uma política monetária que possuísse apenas objetivos nominais (Goodhart, 1995).

\subsection{Emissão de sinais e surpresa}

Uma política monetária para ser eficiente deve emitir nítidos sinais aos agentes a fim de estimulá-los a agir no sentido da direção indicada pelos policymakers. Quanto mais nitidos forem os sinais de política, mais seguros e confiantes estarão os agentes para decidir, assim, maior será o estímulo privado para agir e menor será a intensidade e o tempo de utilização dos instrumentos monetários que serão acionados pelas autoridades. Elas podem sinalizar aos agentes o provável contexto futuro porque são capazes de construir esse futuro - dado o volume de recursos que mobilizam e a notável influência sobre certas variáveis que possuem. Essa reconhecida capacidade de construção de contextos econômicos por parte das autoridades pode estimular os agentes a decidir de acordo com o esperado. Portanto, os sinais emitidos pelas autoridades podem induzir a formação de expectativas auto-realizáveis: agentes acreditam que determinado contexto futuro ocorrerá, então, tomam decisões consistentes com suas expectativas, que terminam por ser validadas pela realidade - dado que os agentes agiram para construir aquele cenário esperado.

- critério da necessidade de emissão de nítidos sinais está rigorosamente de acordo com a concepção de planejamento econômico de Keynes. Para esse autor, o termo planejamento econômico possui um significado mais extenso que política econômica. $O$ primeiro, além de englobar o segundo, refere-se a realização de amplas transformações econômicas, tais como reformas institucionais. ${ }^{10}$ Planejamento $e$, conseqüentemente, políticas econômicas não são, para Keynes, formas de intervenção que significam: controle da economia, fim do princípio da liberdade ou imposição de decisões individuais (CW, v.12, p.238). Pelo contrário, o planejamento econômico deve se restringir a orientar a sociedade e direcionar (ou induzir) decisões privadas. ${ }^{11}$ Portanto, a nitidez das intenções e do modo de ação das autoridades é necessária à indução de decisões/ações privadas. Segundo Tobin $(1987$, p.8), Keynes tinha em

\footnotetext{
${ }^{10}$ Essa definição encontra-se em Cardim de Carvalho (1992, p.209).

11 Cairncross (1992, p.76), percebendo essa importante característica dessas proposições intervencionistas, afirmou: "... Keynes foi um apóstolo da direção econômica mais do que da planificação econômica". Alec Cairncross fez essa afirmativa baseando-se no fato de que a planificação defendida por Keynes é do tipo indicativo. O intervencionismo de Keynes não guarda qualquer semelhança com o planejamento de sentido compulsório adotado nas economias socialistas até o final da década de 1980.
} 
mente algo semelhante ao planejamento francês do pós-guerra em que o governo fomentou e coordenou a emissão de sinais de superação do pessimismo para incentivar decisões de investimento. Nesse sentido, enquanto a nitidez da política monetária é uma necessidade para o pensamento keynesiano, para a teoria novo-clássica, as políticas monetárias que buscam reduzir o desemprego devem se constituir em um segredo que deve ser compartilhado apenas entre policymakers. Para essa última corrente, o elemento surpresa, $\phi$, é imprescindivel.

Para a teoria novo-clássica, não há sentido na utilização dos critérios keynesianos que avaliam a eficiência de politicas monetárias. A utilização de critérios de eficiência por parte do monetarismo novo-clássico implicaria adotar objetivos reais para a política monetária, coordenar instrumentos monetários e fiscais para esse fim e, por último, abrir mão da assimetria de informação: trocar o elemento surpresa pela mais nítida informação.

\section{A ALTERNATIVA DE POLITICA MONETÁRIA DE KEYNES E DOS KEYNESIANOS}

Ao longo da discussão feita nessa seção está subjacente a existência de uma economia com mercado de títulos públicos bastante organizado e que movimenta volumes consideráveis de recursos. Cabe destacar que Keynes elaborou sua teoria da política monetária baseando-se em economias com essas características institucionais, as economias inglesa e americana. Pode-se, contudo, encontrar economias capitalistas organizadas de forma diferente do padrão anglo-americano. A operação da política monetária em muitas dessas economias também pode ser explicada pela teoria de Keynes e dos pós-keynesianos porque o que importa para esses últimos são os efeitos provocados pela ação dos instrumentos disponíveis, quaisquer que sejam eles, sobre as decisões privadas de composição de portfólio. Por exemplo, uma economia que não possui um mercado de títulos desenvolvido, tal como a alemã, mas que possui outros instrumentos que podem induzir os agentes a compor suas carteiras de ativos de forma consistente com o objetivo almejado pode ter a sua política monetária explicada pela teoria de Keynes e dos pós-keynesianos.

Para a visão de Keynes e dos pós-keynesianos, o que importa é que a estrutura institucional existente e seus instrumentos possibilitem a realização de uma política que induza decisões de carteira. Em outras palavras, o relevante é a forma de operar da política monetária e não a existência de determinados instrumentos. Portanto, não é o caso de se propor reformas institucionais profundas para as economias que possuem um padrão de organização diferente do anglo-americano. Reformas institucionais devem ser realizadas em economias que não possuem 
estruturas que possibilitam seus governos operar a política monetária através do estímulo à substitutibilidade entre ativos - tais remodelações foram propostas por Keynes para a economia da Índia no começo desse século objetivando constituir nesse país um ambiente propício à operação deste gênero de política monetária.

Optou-se por continuar a apresentação da teoria da política monetária de Keynes e dos keynesianos em um contexto institucional do tipo angloamericano. Considera-se que aqui não é o espaço adequado para se discutir tal teoria em contextos mais peculiares - assemelhados aos tipos, por exemplo, alemão ou japonês. Fazer essa discussão, baseando-se em modelos mais singulares, não alteraria nem os resultados nem as conclusões, somente dificultaria a trajetória.

\subsection{Instrumentos}

Na visão keynesiana assumida, as autoridades monetárias têm a sua disposição dois instrumentos para utilizar com o intuito de atingir seus objetivos. Podem fazer uso da fixação compulsória de reservas bancárias e das operações de compra e venda no mercado de títulos públicos. $O$ primeiro instrumento afeta a capacidade dos bancos comerciais de conceder crédito de curto termo para satisfazer as necessidades de antecipação de receitas das firmas. Receitas são antecipadas para que sejam validados os compromissos com fornecedores de insumos e para que seja paga a folha salarial. ${ }^{12}$ Logo, a capacidade de antecipação de

12 "Se uma firma decide empregar trabalhadores para utilizar o equipamento de capital para produzir mercadorias, deve possuir suficiente comando sobre recursos monetários para pagar os salários dos trabalhadores e comprar aquelas mercadorias que tem que adquirir de outras firmas durante o período que se expira antes que o produto possa ser, convenientemente e economicamente, vendido por moeda" (CW, v.29, p.64). Em geral, esses recursos monetários são antecipados pelos bancos Keynes acreditava que mesmo aquelas empresas que possuiam uma política de distribuição reduzida de lucros não eram capazes de diminuir a sua dependência em relaçāo sistema bancário Portanto, qualquer. necessidade de recursos deveria ser atendida pelos bancos já que os fundos acumulados por essas empresas, jamais estariam sob a forma dos insumos necessitados ou de moedacash, estariam sob a forma de ativos financeiros que raramente ofereceriam a possibilidade vantajosa de resgate no exato momento que surgia a necessidade de recursos. Logo, por parte das firmas existe a necessidade de antecipação de receitas; e, por parte dos bancos há o interesse em realizar esse tipo específico de empréstimo. Isto ocorre porque esse tipo de empréstimo é mais líquido, dado que seus tomadores transformam rapidamente as mercadorias produzidas, graças ao financiamento bancário, em moeda. Mais ainda, para os banqueiros, esses negócios possuem um turnover curto, envolvem transações freqüentes e são combinados com um elemento que gera segurança: variabilidade de clientes. Nesse sentido, bancos desenvolvem uma útil função à produção em uma economia monetária. Essa longa, mas necessária, nota resume as posições de Keynes sobre o papel dos bancos como 
receitas dos bancos tem uma relação direta com a quantidade produzida pelas firmas. Por essa via, as decisões das autoridades monetárias afetam diretamente as decisões empresariais de produção. O segundo instrumento atinge a taxa de juros que é utilizada como taxa de desconto por capitalistas no cálculo das rendas esperadas de um projeto de investimento, portanto, determina o valor relativo da eficiência marginal do capital - nos moldes do capítulo 11 da General Theory: "uma queda na taxa de juros estimula a produção de bens de capital não porque descresse o seu custo de produção, mas porque cresce o seu preço de demanda" (CW, v. 5 , p.189); ou o "preço [de demanda] dos ativos de capital depende da taxa de juros que capitaliza suas rendas prospectivas" (CW, v.5, p.139). Quando o segundo instrumento é acionado, decisões das autoridades monetárias afetam decisões privadas de investimento. ${ }^{13}$

Para a teoria da política monetária keynesiana, as operações de redesconto de títulos ou de empréstimos de liquidez não são propriamente ferramentas de ação à disposição do banco central. Operações de redesconto são apenas uma obrigação com regras preestabelecidas de compra por parte do banco central de determinados papéis pertencentes aos bancos comerciais, assim como empréstimos de liquidez são auxílios inadiáveis da autoridade monetária aos seus filiados. Tais mecanismos, pelo contrário, dificultam o controle das operações ativas do banco central, assim, dificultando seja o controle da base monetária, seja dificultando a determinação da taxa de juros. A inexistência desses mecanismos anularia, porém, a função de emprestador de última instância do banco central que é essencial para a geração de confiança do público no sistema bancário. Redescontos e empréstimos de liquidez são extremamente necessários, mas dificultam as ações de política monetária, entretanto, não impedem essas ações: o banco central pode desenvolver sua política levando em

provedores de recursos que viabilizam decisões empresariais de produção (ver CW, v.13, p.83-5).

${ }^{13}$ O receituário de política monetária de Keynes é radicalmente diferente do receituário sugerido pelo keynesianismo tradicional, a sintese neoclássica $O$ receituário proposto por essa última tradição advém da constatação empírica que a função demanda por bens de capital possui uma baixa elasticidade-juros. Em conseqüência, a curva IS do diagrama IS-LM seria basicamente vertical. Portanto, com o uso desse instrumental gráfico, seria possivel demonstrar a impotência da política monetária para modificar niveis de renda e emprego, assim como seria possível justificar o caráter fiscalista do keynesianismo americano de L. Klein, W Heller, G.Ackley, O.Eckstein, P.Samuelson, entre outros. Uma versão especial do receituário keynesiano tradicional de política econômica emerge quando associada a essa função demanda por bens de investimento vislumbra-se uma função demanda por moeda com elevadíssima elasticidade juros, assim, a IS seria basicamente vertical e a LM, quase horizontal. Nessa versão especial, o pessimismo das elasticidades caracteriza a situaçâo conhecida como armadilha da liquidez. 
consideração a média de redescontos e empréstimos que costuma realizar; ademais, pode alterar as regras preestabelecidas para o redesconto de certos papéis e/ou impor taxas punitivas de juros para desestimular o pedido de socorro por parte dos bancos afiliados.

Na visão de Keynes e dos keynesianos, a redução dos percentuais de reservas bancárias compulsórias por parte das autoridades monetárias com o objetivo de estimular decisões privadas de investimento seria um erro. Essa redução somente aumentaria as reservas disponiveis dos bancos, mas não estimularia a tomada de crédito com esse fim. Nessas circunstâncias, agentes privados não teriam motivos para alterar seus portfólios adquirindo ativos ilíquidos; comparativamente, papéis financeiros, máquinas ou apartamentos alugados teriam seus retornos esperados inalterados. A utilização do instrumento reservas compulsórias pode aumentar a oferta de fundos para a concessão de empréstimos, mas não estimula o aumento de demanda por esses fundos com a intenção de realização de compras de ativos de capital. Se as autoridades possuem 0 objetivo de promover o investimento, uma política monetária adequada seria aquela que desperta o interesse pela recomposição de portfólios mais ilíquidos (porém, mais rentáveis) e, simultaneamente, provê fundos à economia para que essa estratégia possa ser realizada - tal política é descrita nas duas próximas subseções.

Uma redução das reservas bancárias compulsórias, ceteris paribus, reduz a taxa de juros de curto termo, tal diminuição pode estimular o aumento da produção corrente dado que as firmas fazem parte de uma franja de tomadores insatisfeitos de crédito. Keynes (CW, v.5, p.190 e CW, v.6, p.326-9) cunhou essa expressão para evidenciar o fato que sempre existirão firmas com demandas de crédito não atendidas à taxa de juros corrente se a competição no mercado de crédito é imperfeita. Logo, o aumento da oferta de crédito bancário e a diminuição da taxa de juros podem reduzir o número de potenciais tomadores insatisfeitos e aumentar a produção corrente. Contudo, tal política monetária não pode diretamente induzir os empresários a aumentar a sua capacidade produtiva. $O$ aumento da capacidade de produção somente ocorreria se já existisse uma demanda reprimida por empréstimos para financiar investimentos anterior ao aumento da disponibilidade de crédito bancário.

\subsection{Operação da politica monetária}

banco central opera suas políticas em uma economia monetária que pode ser sinteticamente definida como sendo uma economia de duas esferas de circulação da moeda: a industrial e a financeira (CW, v.5, p.21730). Na primeira, a moeda exerce a sua função de meio de troca, faz girar 
bens e serviços. O produto real, o nível de preços e a velocidade-renda do meio de troca determinam 0 volume de moeda que satisfaz as necessidades dos agentes que atuam nessa esfera. Na segunda, a moeda faz girar ativos financeiros - papéis que possuem uma diversidade de graus de liquidez, exigem diferentes custos de manutenção e podem gerar diferenciados ganhos de juros e ganhos de capital. Nessa esfera, a moeda transforma-se em um ativo que possui os mesmos atributos dos ativos que faz girar: em geral, seu custo de manutenção é nulo, gera ganhos de juros e capital nulos, mas possui liquidez plena - como descrito por Keynes no capítulo 17 da General Theory. Na esfera da circulação financeira, a moeda é um ativo que concorre com os demais ativos pela demanda dos agentes.

Essas esferas não são ilhas isoladas de uma economia monetária. Se assim fosse, na itha da circulação industrial, o quantitativismo seria válido e a moeda seria neutra. Contudo, existe uma ponte que liga essas duas ilhas. Nessa ponte, somente a moeda vai-e-volta. O mesmo objeto, a moeda, quando vai à ilha da circulação industrial transforma-se em meio troca, quando volta à ilha da circulação financeira, transforma-se num ativo, como qualquer outro produto circulante nesse locus. A arte da política monetária keynesiana, que visa ao aumento do produto ou, equivalentemente, à redução do desemprego, é transformar moeda-ativo em moeda meio de troca. A arte é induzir a viagem de moeda da circulação financeira para a circulação industrial. Então, recomenda-se aumentar o estoque monetário da circulação financeira por meio de operações de mercado aberto para reduzir a taxa de juros dos ativos líquidos com o objetivo de estimular estratégias privadas de recomposição de portfólios. Em outras palavras, deve-se estimular a composição de portfólios que contenham itens comercializados na circulação industrial, que não são líquidos, mas que podem render lucros compensadores em relação aos juros oferecidos pelos ativos líquidos da circulação financeira.

Nesse sentido, a política monetária que objetiva o crescimento econômico visa, por um lado, à troca de liquidez por iliquidez e, por outro, à troca de rendimentos de juros por quase-rendas atrativas, isto é, busca desestimular a posse de títulos e estimular a aquisição e uso de máquinas, por exemplo. Assim, esse tipo de política monetária, diferentemente de uma política fiscal de gastos, não age diretamente sobre o produto na circulação industrial. Simplesmente induz o vazamento de moeda em direção a essa circulação. Logo, a política monetária keynesiana que visa ao aumento do investimento tem imediatamente a sua frente não o seu objetivo final, o produto, mas sim agentes que devem agir de acordo com as possibilidades sinalizadas pelo banco central. Contudo, decisões de recomposição de portfólio são tomadas com base em cálculos subjetivos, que envolvem variáveis esperadas - expectativas de cenários futuros. 
Portanto, a eficácia da política monetária não depende exclusivamente da utilização dos seus instrumentos, mas é função, fundamentalmente, das avaliações sobre contextos futuros feitas pelos agentes econômicos. ${ }^{14}$

\subsection{As decisões privadas de composição de portfólio e a eficácia da política monetária}

Além de firmas e indivíduos, entre os agentes que tomam decisões a partir de uma política de operações de mercado aberto estão os bancos. Em geral, bancos são os principais negociantes de papéis; logo, uma compra de títulos por parte do banco central, faz aumentar suas reservas. Essas reservas podem ser complementarmente aumentadas com uma redução do recolhimento compulsório por parte das autoridades monetárias. Com reservas aumentadas, os bancos tomam decisões semelhantes a qualquer agente privado: (i) podem exercer a sua preferência pela liquidez de forma plena, retendo todo o acréscimo de moeda ou (ii) compram papéis financeiros. ${ }^{15}$ Afora essas duas opções, o público não-bancário possui, ainda, uma terceira alternativa: (iii) comprar ativos reais que produzam rendimentos - ativos de capital. Como disse Keynes, "existe sempre uma alternativa à propriedade de ativos de capital real, nomeadamente a propriedade de moeda ou dívidas" (CW, v.7, p.212). Se os agentes econômicos, em geral, e os bancos, em particular, seguem a primeira opção, a política monetária teria efeito nulo sobre o produto. Em verdade, sob tais condições, recursos não vazariam da circulação financeira para a

14 Em Sicsú (1997b) descreve-se uma série de situações em que a política monetária não é capaz de cumprir o seu objetivo, exatamente porque foi rompida a ponte de ligação entre a circulação financeira e a industrial

${ }^{15}$ Os manuais convencionais de ensino de macroeconomia afirmam que quando há uma redução do depósito compulsório bancário ou quando o banco central compra títulos dos bancos comerciais, haverá necessariamente um aumento dos meios de pagamento. Essa afirmativa está contaminada pela visão quantitativista friedmaniana que afirma que a quantidade de moeda da economia é determinada exclusivamente pelas autoridades monetárias. Segundo essa concepção, toda oferta de moeda criada pelas autoridades gera a sua própria demanda por parte do público não-bancário - dado que os bancos são apenas um canal de transmissão monetária, sem qualquer preferência pela liquidez. $O$ keynesianismo de Kaldor e Moore não negou essa visão, somente inverteu o sentido do canal de transmissão Para essa visão, toda a demanda por moeda por parte do público nãobancário é prontamente atendida pelos bancos e passivamente validada pelo banco central. $E$ a demanda que determina a quantidade de moeda da economia - dado que o sistema bancário, sem qualquer preferência pela liquidez, não nega pedidos de moeda-crédito. Em suma, em ambas as visões, aparentemente opostas, bancos são agentes passivos que não tomam decisóes a respeito da quantidade de moeda que deve compor os seus portfolios em cada situação particular. A visão keynesiana aqui assumida nega esses dois extremos. 
circulação industrial. ${ }^{16}$ A despeito das ações do banco central, a recomposição de portfólios se daria pela troca de rendimentos de juros por rendimentos nulos compensados pela troca de ativos líquidos por ativos plenamente líquidos.

Se a segunda opção, de forma generalizada, fosse escolhida por bancos, firmas e indivíduos, a politica monetária poderia produzir desde efeitos nulos até efeitos plenos sobre o produto. Se o aumento de reservas dos agentes econômicos fosse utilizada para a compra de papéis financeiros em mercados secundários, o efeito da política monetária seria nulo. Haveria tão somente uma pressão altista sobre os preços de itens financeiros já existentes. Isto poderia ter ocorrido porque segundo avaliação geral, os ganhos de juros e apreciação e o prêmio de liquidez dos ativos financeiros já existentes superariam os ganhos futuros de lucros dos ativos de capital: "...expectativas referentes ao futuro afetam a situação hoje" (CW, v.7, p.293). Assim, os recursos injetados pelas autoridades monetárias não vazariam da circulação financeira para a circulação industrial; somente produziriam uma recomposição de portfólio entre ativos liquidos. Cabe observar, entretanto, que se existissem firmas desejosas de investir, estas provavelmente lançariam papéis novos no mercado primário com preços e remunerações para concorrer com os ativos financeiros já existentes. Logo, se os agentes optassem pela segunda via dificilmente os resultados seriam completamente nulos.

Se, entretanto, a compra de papéis é feita integralmente em mercados primários de ativos de longo terno emitidos por empresas não-financeiras, isto é, no balcão de firmas desejosas de investir, a política monetária cumpriria integralmente o seu objetivo de reduzir o desemprego. Empresas emitiriam papéis para financiar projetos de investimentos - porque considerariam que o retorno total esperado dos ativos financeiros já existentes não seriam compensadores quando comparados com o retorno total esperado dos ativos de capital. Haveria, portanto, a transformação de moeda-ativo em moeda meio de troca. Contudo, se a compra de papéis fosse feita no balcão de empresas financeiras, o efeito da política monetária dependeria de como essas instituições utilizariam as reservas disponiveis. Tais instituições poderiam reter os recursos monetários ou poderiam comprar ativos financeiros em mercados secundários ou primários de outras empresas financeiras ou de empresas não-financeiras. Logo, quando a segunda opção é predominantemente escolhida pelos agentes, os efeitos reais (mais intensos ou menos intensos) da política monetária expansionista

\footnotetext{
${ }^{16}$ Foi por isso que Keynes disse que "...se, entretanto, nós estamos tentados a afirmar que a moeda é a bebida que estimula o sistema para a atividade, devemos lembrar que podem existir alguns contratempos entre a taça e os lábios" (CW, v.7, p.173).
} 
de reservas são função, primeiro, da intensidade das compras nos mercados primário ou secundário de papéis financeiros $e$, segundo, da intensidade das compras nos mercados primários de empresas financeiras ou não-financeiras.

Se a terceira via fosse escolhida pelo público não-bancário e os bancos comprassem nos mercados primários ativos financeiros das firmas desejosas de investir, a política monetária teria efeito pleno sobre o produto e o emprego. O público não-bancário recomporia seu portfólio preterindo papéis e preferindo ativos de capital e os bancos emprestariam recursos às firmas investidoras. ${ }^{17}$ Portanto, os recursos injetados pelas autoridades monetárias vazariam integralmente da circulação financeira para a circulação industrial. Assim, a descrição das três vias demonstrou que a eficácia da política monetária que visa à redução do desemprego dependerá, por um lado, das ações das autoridades monetárias e, por outro, das reações dos bancos, firmas e individuos. Mais precisamente: dependerá em última instância da forma pela qual esses segmentos desejam compor os seus portfólios. ${ }^{18}$

Objetivos, critérios de eficiência, instrumentos e a forma de operação da política monetária sugerida por Keynes e pelos pós-keynesianos já foram apresentados. Entretanto, cabe destacar que os instrumentos não atingem diretamente os objetivos finais, atingem agregados monetários e taxas de juros, simultaneamente. São as mudanças no valor dessas variáveis que induzem as decisões privadas. Nenhuma forma de política monetária pode controlar diretamente as decisões individuais, tão somente controlam metas intermediárias (ou variáveis intermediárias) que são as taxas de juros ou os agregados monetários. Keynes optou pelo controle da taxa de juros como

17 Indicou-se a presença de três segrmentos - indivíduos, firmas e bancos - sem qualquer tratamento hierárquico. Contudo, assume-se implicitamente as palavras de Keynes da seguinte passagem. "o aumento da riqueza acumulada da comunidade em qualquer período de tempo depende principalmente de empresários e financistas ... e não das decisōes do corpo de cidadāos individuais que poupará parte das suas rendas monetárias" (CW, v.5, p. 283).

${ }^{18}$ A visão de Friedman sobre os efeitos reais da política monetária derivam também de análises baseadas em decisóes de composição de portfolio dos agentes. Para esse autor, os agentes económicos mantêm seus portfolios com proporçōes fixas maximizadoras de satisfaçåo entre diversos itens (ativos financeiros, bens de capital, bens de consumo duráveis, capital humano e moeda); um aumento de reservas monetárias provocaria uma mudança de proporção não desejada que é imediatamente anulada com a transformação do excesso monetário nos demais ativos até que a proporção original seja novamente alcançada. "Assim a moeda influencia a renda como um todo, não unicamente o investimento" (Chick, 1992, p.137). Para maiores detalhes sobre o modelo monetarista de composição de portfolio, ver Friedman (1956) e Davidson (1978, p.93-4, nota 1 , principalmente, p 196-7, inclusive a nota 2) 
meta intermediária da política monetária - e não pelo controle quantitativo de agregados monetários. Contudo, do ponto de vista teórico, quem controla preços (a taxa de juros) pode controlar quantidades (agregados monetários) e vice-versa. A opção de Keynes, com toda a certeza, não está fundada em argumentos teóricos: o pragmatismo da política monetária ensejou essa opção. Keynesianos reconhecem que operacionalmente o controle de agregados monetários seria extremamente árduo: movimentos na demanda por moeda são de difícil previsão considerando o timing de ação dos instrumentos, assim como movimentos de oferta através de inovações financeiras dificultam o controle das autoridades durante determinado tempo. ${ }^{19}$

\section{SUMÁRIO E CONCLUSÕES}

Inicialmente, foi descrito o mais conhecido modelo novo-clássico que supõe a ineficácia da política monetária. Adotando a hipótese da taxa natural desemprego, o modelo de Sargent \& Wallace (1981) mostra que políticas monetárias somente afetam variáveis reais se, e somente se, causam surpresa aos agentes. Contudo, transcorrido o tempo necessário para que trabalhadores e empresários entendam que foi uma variação inesperada de oferta monetária que propiciou o aumento da produção, refazem suas decisões: fazendo a economia retornar ao ponto correspondente à taxa natural de desemprego. Kydland \& Prescott (1994) afirmaram que a possibilidade de surpresa pode inexistir porque os agentes acabam por incorporar nos seus modelos subjetivos decisórios as regras de política monetária que não são explicitadas por policymakers. Sendo assim, gestores da política monetária contaminados pelo viés inflacionário (inflationary bias) poderiam provocar exclusivamente inflação. Assim, o desemprego não poderia ser reduzido, nem mesmo temporariamente como propuseram Sargent \& Wallace. A política monetária seria ineficaz em quaisquer condições.

A hipótese básica dos modelos de política monetária da teoria novoclássica foi criticada. Mostrou-se que a economia não gravita nem em torno nem em direção a uma posição de equilíbrio. Argumentou-se que a propriedade da estabilidade do equilibrio não vigoraria se as expectativas, ainda que racionais, podem ser heterogêneas. Sendo assim, necessariamente se as expectativas podem ser heterogêneas, haveria decepção de expectativas, erros ocorreriam. Erros podem, por sua vez, induzir a haver mudanças dos parâmetros que conformam a posição de

\footnotetext{
19 Uma publicação revelando as dificuldades dos dirigentes de diversos bancos centrais em controlar os agregados monetários foi organizada por Meek (1982).
} 
equilíbrio correspondente à taxa natural de desemprego. Conseqüentemente, a propriedade da unicidade também não seria válida. A alternativa pós-keynesiana à taxa natural de desemprego é o conceito de economia monetária. Nesse conceito, a economia pode permanecer repousada em infinitas posições aquém do pleno emprego sem que existam, obviamente, forças endógenas capazes de fazer a economia se dirigir a uma posição próxima do pleno emprego.

Se não existem forças econômicas capazes de reduzir o desemprego quando este torna-se socialmente insustentável, concluiu-se que algo deve ser feito de fora para dentro da economia. Como o uso dos instrumentos de política monetária foi considerado potente para auxiliar nessa empreitada, critérios para a utilização eficiente da política monetária discricionária foram estabelecidos. Uma política monetária discricionária eficiente seria aquela que cria o mínimo de utilização contraditória entre seus instrumentos e os instrumentos de outras políticas econômicas, persegue um objetivo prioritário e emite sinais estimuladores de decisões privadas consistentes com a meta governamental almejada. Sendo assim, uma política monetária eficiente seria aquela que tenta preparar um ambiente macroeconômico propício, isto é, que facilite e induza decisões privadas consistentes com o objetivo desejado.

Descreveram-se os instrumentos e os mecanismos de operação da política monetária em um contexto institucional do tipo anglo-americano. Os instrumentos apontados foram as reservas compulsórias bancárias e as operações de open-market. Mostrou-se que a política monetária discricionária sugerida por Keynes deve ser manipulada visando à promoção da substitutibilidade entre ativos componentes das carteiras privadas. Por exemplo, se o objetivo é reduzir o desemprego, as autoridades deveriam reduzir a taxa de juros que estimula a aquisição de ativos líquidos. Em conseqüência, agentes econômicos seriam induzidos a reavaliar os rendimentos dos seus portfólios e, possivelmente, a fazer planos de recomposição de suas carteiras. É provável que, sob tais condições, uma parte considerável dos recursos disponíveis fosse destinada à aquisição de ativos de capital, que embora menos líquidos teriam uma rentabilidade compensadora se comparada com os ativos financeiros líquidos. Assim, a política monetária reduziria o desemprego.

\section{BIBLIOGRAFIA}

CAIRNCROSS, A. Economía y Politica Económica. México: F.C. Económica, 1992.

CARDIM DE CARVALHO, F. Mr. Keynes and the Post Keynesians Cheltenham: Edward Elgar, 1992

CHICK, $V$. On Money, Method and Keynes. London. MacMillan, 1992.

The Theory of Monetary Policy. Oxford: Blackwell, 1993. 
CW. The Collected Writings of John Maynard Keynes (30 vol.). London: MacMillan $\theta$ Cambridge: Camb. Univ.Press.

DAVIDSON, P. Reviving Keynes' Revolution. Journal of Post Keynesians Economics, $v 6$, n. 4, p. 585-90, 1984 International Money and Real World. New York: John Wiley \& Sons, 1982 Money and the Real World. London: MacMillan, 1978.

FRIEDMAN, M The Role of Monetary Policy, American Economic Review, Mar, p.117,1968

M. The Quantity Theory of Money: a Restatement In: Friedman, M. (ed.), Studies in the Quantity Theory of Money. The University of Chicago Press, 1956

GOODHART, C. Central Banking and the Financial System London: Macmillan, 1995

HAHN, F. Equilibrium and Macroeconomics. Oxford: Basil Blackwell, 1984 Money and inflation. Cambridge (Mass): MIT Press, 1983

HAYEK, F. Desemprego e Política Monetária. R Janeiro J. Olympio e Inst Liberal, 1985

KENAN, W. Challenge to the Natural Rate Doctrine Journal of Post Keynesian Economics, V. 17, n. 1, p.159-161, 1994.

KREGEL, J. Constraints on the Expanasion of Output and Employment: real or monetary?, Journal of Post Keynesian Economics, v. 7, n. 2, p.139-152, 1984/5.

MEEK, P. (ed.). Central Banks Views on Monetary Targetting. New York The Federal Reserve Bank of New York, 1982

MOGGRIDGE, D Keynes. London: MacMillan, 1993

MUTH, J Rational Expectations and the Theory of Price Movements. Econometrica, v. 29, $n$. 3. p.315-335, 1961.

SARGENT, T. \& WALLACE, N. Rational Expectatios and the Theory of Economic Policy. In: LUCAS, R. \& SARGENT, T.(eds), Rational Expectations and Econometric Practice, Minneapollis: University of Minnesota Press, 1981.

SHULMAN, S. The Natural Rate of Unemployment concept and critique Journa of Post Keynesian Economics, v. 11, n. 4, p.509-521, 1989.

SICSÚ, J. Eficácia e Credibilidade da Política Monetária Discricionária: uma abordagem keynesiana. Tese de Doutorado, I. Economia da UFRJ, Rio de Janeiro, $1997 a$.

Reputação das Autoridades Monetárias e Credibilidades das suas Políticas: uma abordagem pós-keynesiana. Estudos Econômicos, v. 27, n.1, jan /abr.: p.5-27, $1997 \mathrm{~b}$.

SIMONSEN, M.H. Keynes versus Expectativas Racionais. Pesquisa e Plonejamento Econômico, v. 16, n. 2, p.251-262, 1986.

TINBERGEN, J. On the Theory of Economic Policy. Amsterdam: North-Holland, 1952

TOBIN, J. Essays in Economics: National and International Cambridge: MIT Press, 1996. Policies for Porsperity. Sussex. Wheatsheaaf Books, 1987.

Essays in Economics: Macroeconomics. Chicago: Markhan, 1972.

WICKSELL, K. Lições de Economia Politica. São Paulo: Nova Cultural, 1986. 